\title{
OLIMPIANO DIGITAIS ENTRE A GLÓRIA E O JULGAMENTO
}

\section{ARTIGO ORIGINAL}

VIEIRA, Larissa Fernandes Portella ${ }^{1}$, ROCHA, Natália de Andrade ${ }^{2}$

VIEIRA, Larissa Fernandes Portella. ROCHA, Natália de Andrade. Olimpiano digitais entre a glória e o julgamento. Revista Científica Multidisciplinar Núcleo do Conhecimento. Ano. 07, Ed. 01, Vol. 04, pp. 184-223. Janeiro de 2022. ISSN: 24480959, Link

acesso: https://www.nucleodoconhecimento.com.br/comunicacao/olimpiano-digitais

\section{RESUMO}

A internet se tornou, nos últimos anos, cada vez mais presente na vida das pessoas e acarretou profundas mudanças sociais, especialmente no que se refere à formas de comunicação. As inovações tecnológicas trouxeram à vida redes de relacionamento mediadas pela tecnologia, fazendo surgir novos papéis no contexto das interações entre os indivíduos: os influenciadores digitais e os consumidores de seus conteúdos. O presente trabalho é motivado pelo objetivo de entender como os influenciadores digitais percebem o contato direto e constante com os seus seguidores, sendo assim, a pergunta problema deste estudo é a seguinte: Qual a percepção que influenciadores digitais do instagram possuem sobre o contato constante com o seu público, através das redes sociais, em relação ao seu bem-estar e saúde da mente? Para trazer compreensão à temática abordada, foram utilizados estudos de pensadores, como: Manuel Castells, Pierre Lévy, Zygmunt Bauman, Edgar Morim e outros que contribuem

\footnotetext{
${ }^{1}$ Bacharel em Publicidade e Propaganda - Tecnólogo em Publicidade e Propaganda. ORCID: 0000-0003-3817-9144

2 Orientador.
}

RC: 105265

Disponível em: https://www.nucleodoconhecimento.com.br/comunicacao/olimpiano-digitais 
no entendimento sobre a comunicação na modernidade, as redes sociais e as celebridades da internet. A pesquisa é de natureza exploratória e para a sua realização foram utilizados dados qualitativos, dessa forma, foram feitas entrevistas em profundidade com cinco influenciadores digitais do instagram que produzem conteúdo para o público feminino, além de levantamento bibliográfico para reforçar e estimular o entendimento. Os resultados dos estudos revelam que embora os influenciadores entrevistados percebam os pontos positivos no que fazem, os desafios e a pressão de serem participantes ativos nas redes digitais de relacionamento também são reconhecidos e capazes de afetá-los mentalmente de forma negativa, ratificando a hipótese apresentada.

Palavras-chave: Internet, redes sociais, influenciadores digitais, comunicação.

\section{INTRODUÇÃO}

A facilitação do acesso à internet trouxe significativas mudanças na sociedade, sobretudo no surgimento de novas formas de interação. As redes sociais da internet integram este cenário tornando-se cada vez mais presentes no modo de vida contemporâneo.

O sociólogo Manuel Castells (1999, p. 497), pioneiro na pesquisa das consequências da sociedade em rede a partir do fenômeno da internet, acredita que as redes constituem "a nova morfologia social de nossas sociedades, e a difusão da lógica de redes modifica de forma substancial a operação e os resultados dos processos produtivos e de experiência, poder e cultura.".

É importante frisar que embora o termo "redes sociais" esteja associado à internet, elas antecedem a existência desta inovação tecnológica. As sociedades sempre viveram em redes, como a família, o trabalho, os amigos, as comunidades, entre outros. O que a modernidade trouxe, então, foram as redes mediadas por aparatos tecnológicos (ALENCAR, 2014).

RC: 105265

Disponível em: https://www.nucleodoconhecimento.com.br/comunicacao/olimpiano-digitais 
Recuero (2009) afirma que as redes sociais online são grupos de atores que se constituem através da interação mediada pelo computador. Pertinente declarar que essas plataformas criadas para a interação se tornaram um dos principais canais de divulgação de ideias, produtos e conceitos. É a partir dessa evolução que surgem os influenciadores digitais, indivíduos que exercem influência sobre os consumidores que navegam nos espaços virtuais.

No estudo das teorias da comunicação é possível constatar que os receptores de uma mensagem já foram considerados passivos. A teoria hipodérmica supunha que a mensagem midiática enviada à um público de massa afetava da mesma maneira a todos os indivíduos (WOLF, 1999). Esse conhecimento foi refutado por novos saberes surgidos com o passar dos anos. Como exemplo, a teoria dos usos e gratificações que procurou descobrir o que o público fazia com as mensagens da mídia e entendeu o consumidor de mídia como ator racional que buscava satisfazer necessidades específicas através daquele conteúdo. Ambas as teorias foram formuladas antes do advento da internet e ainda trazem a ideia de persuasão ou dominação midiática, porém, esta segunda, é válida na sua percepção de que o consumidor é consciente e busca a satisfação própria (DALMONTE, 2008, p. 8).

A internet traz à realidade o encontro e mistura entre emissor, receptor e mensagem. Entende-se que a comunicação aqui não acontece em um processo linear, mas circular, no qual emissores e receptores estão em constante troca. Dito isso, pensemos no papel do influenciador digital neste cenário. Ao postar conteúdo nas redes sociais[3], cumprindo o papel de emissor, essa lhe devolve feedback imediato. As redes, compostas por pessoas, permitem a interação instantânea, e, portanto, o gerador de conteúdo torna-se receptor das mensagens, opiniões e comentários de seu próprio público.

Como citado anteriormente, os receptores de conteúdo não são passivos como acreditava a teoria hipodérmica (WOLF, 1999) e buscam satisfação própria como

RC: 105265

Disponível em: https://www.nucleodoconhecimento.com.br/comunicacao/olimpiano-digitais 
afirma a teoria dos usos e gratificações (DALMONTE, 2008). Dessa forma, os influenciadores digitais ficam expostos a uma situação controversa. Embora as plataformas sociais sejam essenciais para o seu trabalho, a intensa proximidade com seus seguidores pode gerar desconforto e a sensação de nunca estar agradando a todos eles.

À vista disso, a hipótese norteadora deste estudo é a de que os influenciadores digitais estão expostos a contínua pressão decorrente do contato direto e íntimo com o público através das redes sociais, e, dessa forma, podem apresentar percepções negativas desse contato sobre a sua saúde mental[4]. Considerando tal colocação, faz-se a seguinte pergunta: Qual a percepção que influenciadores digitais do instagram possuem sobre o contato constante com o seu público, através das redes sociais, em relação ao seu bem-estar e saúde da mente? Objetiva-se identificar qual é essa percepção, através de diálogo com os mesmos, para análise de suas opiniões.

Como ponto de partida foi utilizado o conhecimento obtido com as Teorias da comunicação[5]. Encontramo-nos atualmente em um contexto de imersão midiática e fluxo contínuo de vídeo, áudio, fotos e textos que nos acompanha diariamente. Portanto vê-se a necessidade de entender essa nova relação entre a audiência, os emissores e as múltiplas mensagens. O foco desta pesquisa está voltado para os produtores de conteúdo na internet como audiência das opiniões de seu próprio público.

\section{METODOLOGIA UTILIZADA NA PESQUISA}

A presente pesquisa é de natureza exploratória. Para esse fim, foram utilizados dados qualitativos com o intuito de propiciar um maior conhecimento sobre a percepção que os influenciadores digitais têm do contato direto com seu público em relação ao seu bem-estar e saúde mental. Desta forma, apresenta planejamento flexível e utiliza-se de levantamento bibliográfico, assim como de análise de exemplos para estimular a

RC: 105265

Disponível em: https://www.nucleodoconhecimento.com.br/comunicacao/olimpiano-digitais 
compreensão. Tais características foram mencionadas por Antônio Carlos Gil (2002) para definir o estudo exploratório:

\begin{abstract}
Estas pesquisas têm como objetivo proporcionar maior familiaridade com o problema, com vistas a torná-lo mais explícito ou a constitui hipóteses. Pode-se dizer que estas pesquisas têm como objetivo principal o aprimoramento de ideias ou a descoberta de intuições. Seu planejamento é, portanto, bastante flexível, de modo que possibilite a consideração dos mais variados aspectos relativos ao fato estudado.
\end{abstract}

Na maioria dos casos, essas pesquisas envolvem: (a) levantamento bibliográfico; (b) entrevistas com pessoas que tiveram experiências práticas com o problema pesquisado; e (c) análise de exemplos que "estimulem a compreensão". (GIL apud SELLTIZ, 2002, p. 41)

A coleta de dados aconteceu de duas formas. A primeira por meio de levantamento e análise de material bibliográfico e documental nas áreas de comunicação e psicologia sobre o comportamento humano e sua forma de lidar com a modernidade. A segunda através de entrevistas em profundidade com influenciadores digitais sob uma perspectiva qualitativa.

As entrevistas foram realizadas de forma online e individual e para tal foi criado um roteiro semiestruturado. O universo compõe-se de cinco influenciadores digitais do Instagram que produzem conteúdo voltado ao público feminino, residentes em território nacional, independentemente de sua idade. Os entrevistados responderam perguntas relacionadas ao tempo gasto em redes sociais, ao bem-estar perante a pressão imposta por seguidores e a autopercepção diante da própria saúde mental (APÊNDICE I).

Para análise dos dados, após diálogo com os cinco influenciadores digitais do Instagram, foi realizada uma descrição detalhada da conversa, destacando os pontos mais importantes para a pesquisa com o objetivo de compreender por meio das respostas oferecidas a veracidade da hipótese deste projeto.

RC: 105265

Disponível em: https://www.nucleodoconhecimento.com.br/comunicacao/olimpiano-digitais 


\section{O CIBERESPAÇO E A CIBERCULTURA}

O ciberespaço surgiu da interconexão de computadores. O termo foi idealizado no livro Neuromancer (GIBSON, 1984) e referia-se a um espaço virtual composto por cada computador e usuário conectados em uma rede mundial.

O ciberespaço apresenta-se como um novo lugar de sociabilidade e acaba por originar novas formas de relações e implicações culturais que o filósofo Pierre Lévy chamou de cibercultura (1999). "Não é a cultura dos fanáticos da Internet, é uma transformação profunda da noção mesma de cultura" (MURAD apud LÉVY, 2005).

Desde que o computador foi criado em 1945, nos Estados Unidos da América e na Inglaterra, as inovações e reformulações desse suporte e sistema de processamento de dados não param de ser ampliadas a partir das criações humanas. (SIMÕES, 2009, p. 3)

Dessa forma, a internet deve ser compreendida pela relação entre as pessoas, as informações e os computadores. A rede é formada por essa interconexão e não existiria sem a associação entre esses três elementos. Ela permite uma nova forma de comunicar, não possível pela comunicação de massa.

O aspecto principal que deve ser observado, no que diz respeito à comunicação, é a mediação que ao mesmo tempo é interativa e massiva, ou na lógica indicada por Lévy, avançando ao longo dos modelos UM- TODOS, UM-UM, para TODOS-TODOS. (SIMÕES, 2009, p. 9).

Importante entender que as tecnologias não determinam as mudanças, mas as condicionam à medida que criam condições para que elas ocorram. Entretanto é verdadeira a impossibilidade de ignorar o impacto das inovações tecnológicas na vida e sociedade e, especialmente, nas formas de interação.

RC: 105265

Disponível em: https://www.nucleodoconhecimento.com.br/comunicacao/olimpiano-digitais 


\subsection{AS TEORIAS DA COMUNICAÇÃO APLICADAS AO CIBERESPAÇO}

Uma vez que a comunicação é parte essencial da vida humana, entendê-la é questão relevante. As tecnologias, surgidas para aperfeiçoar e facilitar a vivência dos indivíduos, buscam também amplificar a capacidade comunicacional do homem (MCLUHAN, 1964). Podemos citar os meios de comunicação de massa como uma das principais transformações visando essa amplificação.

A competência desses meios, as mensagens enviadas por eles, os receptores dessas mensagens e a forma como elas os influenciam, são temas alvos de curiosidade e interpretações até os dias atuais.

Falava-se inicialmente em uma sociedade de massa. A massa traduz o que é homogêneo, ou seja, entendia-se que os indivíduos de massa eram atingidos pelos estímulos midiáticos e respondiam a eles de forma igual e pretendida.

Por conseguinte, segundo a teoria hipodérmica, «cada indivíduo é um átomo isolado que reage isoladamente às ordens e às sugestões dos meios de comunicação de massa monopolizados» (Wright Mills, 1963, 203). Se as mensagens da propaganda conseguem alcançar os indivíduos que constituem a massa, a persuasão é facilmente «inoculada». Isto é, se o «alvo» é atingido, a propaganda obtém o êxito que antecipadamente se estabeleceu. (WOLF, 1999, p. 8)

É sabido hoje que essa percepção é demasiadamente superficial para compreender a sociedade e a comunicação. Para entender os processos comunicacionais surgidos após a popularização da internet, é importante considerar os saberes adquiridos anteriores à sua existência. Um olhar atento sobre eles ajudará a compreender o receptor, emissor e a troca entre eles na comunicação mediada pelo computador.

A teoria da persuasão diferenciou-se de sua antecessora ao defender que a mensagem enviada pela mídia não é assimilada imediatamente e depende de

RC: 105265

Disponível em: https://www.nucleodoconhecimento.com.br/comunicacao/olimpiano-digitais 
perspectivas individuais. O indivíduo tende a se interessar por informações que estejam inseridas em seu contexto, assim sendo, a mídia não exerce papel dominador ou manipulador, mas sim, o da persuasão.

"Persuadir os destinatários é um objetivo possível, se a forma e a organização da mensagem forem adequadas aos fatores pessoais que o destinatário ativa quando interpreta a própria mensagem”. (WOLF, 1999, p. 12)

$\mathrm{Na}$ internet encontramos variedade de informações contadas em multiplicidade de formas. O receptor é vulnerável a ser persuadido por elas, porém, somente será atingido desta forma por aquelas que se enquadrem em suas crenças, cultura e conhecimentos. Isso é reforçado pela teoria empírica de campo, a qual entende-se que a mídia tem influência limitada na sociedade, assim como qualquer força social. Ou seja, existem filtros inerentes a cada pessoa pelos quais as mensagens passam.

O que ocorre na internet é que além da existência do filtro natural, há também os próprios filtros na rede: os algoritmos. Dessa forma, os assuntos mais comentados tendem a aparecer para as pessoas, mas estão também relacionados às preferências, históricos e comportamentos. Ou seja, o usuário acaba cercado justamente pelas informações que exercem capacidade de influência sobre ele. São as "denominadas bolhas sociais, espécie de confinamento informático ao qual são submetidos os usuários de ferramentas on-line." (JÚNIOR; PELLIZARI, 2019, p. 1).

Portanto os receptores são conscientes, racionais e buscam informações que satisfaçam suas vontades individuais. A comunicação mediada pelo computador eleva isso a um novo nível, os destinatários de uma mensagem nunca antes tiveram tanta voz ou relevância. A internet possibilita rápida aceitação ou rejeição dos conteúdos, além da troca constante nos papéis entre quem envia e quem recebe a informação.

RC: 105265

Disponível em: https://www.nucleodoconhecimento.com.br/comunicacao/olimpiano-digitais 


\subsection{A INTERAÇÃO MEDIADA E SUAS TRANSFORMAÇÕES}

A principal transformação que a internet trouxe diz respeito as formas de comunicação com outrem. $O$ ato de comunicar pode ser traduzido como a capacidade de compreensão e interação entre dois ou mais indivíduos. Na interação mediada, essa transação comunicativa ocorre por meio da utilização de um aparato tecnológico.

[...] aquilo que está mudando profundamente as formas de organização, identidade, conversação e mobilização social: o advento da Comunicação Mediada pelo Computador. Essa comunicação, mais do que permitir aos indivíduos comunicar-se, amplificou a capacidade de conexão, permitindo que redes fossem criadas e expressas nesses espaços: as redes sociais mediadas pelo computador. (RECUERO, 2009, p. 16)

O ser humano é um ser de comunicação por natureza e, como tal, busca desde os primórdios formas de realizar essa ação, seja por grunhidos, desenhos, gestos ou a palavra. A comunicação é parte inerente do indivíduo.

Dessa forma, é fácil compreender a popularização das redes digitais de relacionamento, surgidas com o advento da comunicação mediada pelo computador.

Ao realizar um breve estudo sobre as redes sociais Telles $(2018, p .3)$ explica que a concepção de rede sociais têm cerca de um século e se propunha a designar um "conjunto complexo de relações entre membros de um sistema social de diferentes dimensões". Explica o autor (TELLES, 2018, p. 3) que as redes sociais de internet tiveram seu surgimento por volta do século XXI que seus conceitos, sob o aspecto sociológico permanecem inalterados.(SIMAS; JÚNIOR, 2018, p. 3)

As redes expandem a capacidade de interação entre as pessoas e independem da distância ou tempo para realizar essa conexão. Em razão disso, e por seu caráter facilitador e atrativo tornam-se virais e essenciais no mundo moderno e tecnológico em que vivemos hoje.

RC: 105265

Disponível em: https://www.nucleodoconhecimento.com.br/comunicacao/olimpiano-digitais 


\subsection{OS INFLUENCIADORES DIGITAIS NO INSTAGRAM}

O Instagram, uma das maiores e mais populares redes sociais atualmente, foi criado por Kevin Systrom e Mike Krieger e lançado em outubro de 2010 (VILICIC, 2015). Trata-se de um aplicativo para compartilhamento de fotos e vídeos, que permite a conexão tanto de pessoas como de empresas.

"As redes sociais permitem interações multifacetadas e eletivas, sendo cada um dos atores potenciais formadores de opinião, pessoas capazes de impactar as percepções ao seu redor." (SIMAS; JÚNIOR, 2018). Esses espaços virtuais possibilitam e facilitam que indivíduos comuns exerçam diferentes graus de influência sobre outros.

Recuero (2009) declara que os indivíduos almejam fama e popularidade. Ambos os valores são encontrados nas redes digitais de relacionamento.

Uma das formas de sociabilização que veio à tona é o Instagram, uma rede social que se tornou uma vitrine no espaço virtual. Nele os indivíduos são condicionados a algumas práticas sociais, como a exposição acentuada de sua vida, reproduzindo ao mundo sua intimidade, experiências e relações de consumo. Assim, esses indivíduos demonstram como desejam ser vistos e criam sua identidade através da imagem que querem ser percebidos. (GREGGIANIN; WIMMER, 2018, p. 2)

Uma pesquisa realizada pelo Social Media Trends (2018) mostrou que $47,1 \%$ dos respondentes consideram o Instagram a sua rede social favorita. De acordo com Silva (2012) o Instagram está na moda, expondo consigo o ponto de vista da intimidade, das relações de consumo e das experiências do sujeito. Tal exposição pressupõe uma espera ou convicção na promessa de ser visto, não ser esquecido.

Assim, essa plataforma apresenta-se como favorável para a ingressão ou nascimento dos influenciadores digitais. "O termo influencer digital se refere àquelas pessoas que se destacam nas redes e que possuem a capacidade de mobilizar um grande número

RC: 105265

Disponível em: https://www.nucleodoconhecimento.com.br/comunicacao/olimpiano-digitais 
de seguidores, pautando opiniões e comportamentos e até mesmo criando conteúdos que sejam exclusivos" (SILVA; TESSAROLO, 2016, p. 5).

Esses indivíduos atingem um alto nível de popularidade e reconhecimento dentro de seu nicho virtual, e, às vezes, fora dele. Expondo a vida pessoal, utilizando filtros, gravando e postando detalhes embelezados da vida cotidiana, eles são essencialmente parte da cultura da internet e, como tal, ganham cada vez mais relevância no atual mundo conectado.

\section{OS INFLUENCIADORES DIGITAIS COMO AS CELEBRIDADES CONTEMPORÂNEAS}

Nos tempos atuais, especialmente devido à mídia, o conceito de celebridade é popular. A ideia de celebridade, no entanto, é concebida muito antes do surgimento dos meios de comunicação de massa. Os grandes reis, os guerreiros e o clero já apresentavam, em tempos idos, ideais e exemplos a serem seguidos, almejados e admirados. (MOREIRA; RIOS, 2016, p. 2)

No passado, identificar os indivíduos célebres e a razão de sua fama era tarefa mais fácil. Esse status surgia como resultado de um trabalho bem-feito, reconhecimento do talento ou da posição social de um indivíduo, porém se tornar celebridade cada vez menos trata-se de uma conquista, mas de uma projeção imagética. "Desse modo e principalmente devido aos tempos atuais de ampla exposição midiática, uma pessoa comum pode se tornar célebre apenas por sua imagem, sem ter obtido uma função social definida ou realizado alguma coisa importante." (MOREIRA; RIOS, 2016, p. 1).

Edgar Morin (1962) chamou de "Olimpianos" os astros de cinema, membros da realeza, playboys, artistas, entre outros indivíduos que pertencem a um tipo de "Olimpo"[6]. Eles são parte de uma troca entre o imaginário e o real e se situam em um cenário de projeção-identificação.

RC: 105265

Disponível em: https://www.nucleodoconhecimento.com.br/comunicacao/olimpiano-digitais 
Segundo o autor, devido a sua capacidade de transformar algo pífio em um grande evento, a mídia foi responsável por gerar confinidade entre os "deuses" e os "meros mortais". As grandes celebridades de Hollywood começaram a se tornar acessíveis em razão da "proximidade" permitida pelos meios de massa. Ganha força nesse cenário o culto a essas personalidades célebres com a ideia de que a estrela está mais presente, quase a disposição de seus admiradores, fazendo surgir fã-clubes, revistas, fotografias, correspondências etc.

Esses olimpianos propõem o modelo ideal da vida de lazer, sua suprema aspiração. Vivem segundo a ética da felicidade e do prazer, do jogo e do espetáculo. Essa exaltação simultânea da vida privada, do espetáculo, do jogo é aquela mesma do lazer, e aquela mesma da cultura de massa. (MORIN, 1962, p. 75).

Vivemos na era da cibercultura (MONTEIRO, 2019) e, portanto, é natural o surgimento das celebridades da internet. Esse momento traz à tona as celebridades do cotidiano, onde estranhos são capacitados ao status de fama meramente pela construção de sua imagem através das redes sociais.

Morin (1962) acreditava na existência de uma dupla natureza dada aos olimpianos pela cultura de massa: a natureza da projeção e da identificação. Dessa forma, os mortais ao mesmo tempo que se identificam com as personalidades, projetam suas vontades à essas figuras.

A projeção diz respeito ao ideal de que as celebridades possuem uma vida melhor, a qual os demais indivíduos gostariam de viver, mas, por algum motivo, não podem. Assim, projetar as vontades pessoais nas vivências dos olimpianos "serve de consolo para a vida que nos falta, nos servem de distração para a vida que nos é dada" (MORIN, 1966, p. 166).

Já a identificação ocorre graças ao espetáculo que se torna a vida dos olimpianos. Quando entramos em contato com notícias sobre os namoros, as compras, a família

RC: 105265

Disponível em: https://www.nucleodoconhecimento.com.br/comunicacao/olimpiano-digitais 
ou qualquer aspecto da vida pessoal dessas personalidades, encontramos similaridade com as nossas próprias experiências.

\begin{abstract}
A informação transforma esses olimpos em vedetes da atualidade. Ela eleva à dignidade de acontecimentos históricos acontecimentos destituídos de qualquer significação política, como as ligações de Soraya e Margaret, os casamentos ou divórcios de Marilyn Monroe ou Liz Taylor, os partos da Gina Lollibrigida, Brigitte Bardot, Farah Diba ou Elizabeth da Inglaterra. (MORIN, 1962, p. 105)
\end{abstract}

O influenciador digital é responsável por promover a si mesmo nas redes sociais e ao trabalhar a sua imagem acaba por gerar na sua relação com os seguidores a mesma dupla natureza dos olimpianos.

Neste cenário a identificação é ainda maior, uma vez que se trata de pessoas comuns, outrora anônimas. Os influencers digitais são considerados "gente como a gente", e, portanto, é natural a identificação com eles. Porém, o sentimento de projeção também é real. A ideia de ganhar reconhecimento postando conteúdos online permeia os pensamentos dos indivíduos atualmente, especialmente os mais jovens.

São os próprios influenciadores, na maioria das vezes, os responsáveis por transformar em um espetáculo as suas vidas pessoais. As redes sociais, em especial o Instagram, portam-se como uma vitrine de suas "vidas perfeitas", ao mesmo tempo em que geram intimidade com o público através dos stories, directs etc.

Porém, se as inovações tecnológicas mudaram a nossa forma de comunicar e relacionar com o outro, é observável também que a relação celebridade-fã não saiu ilesa. Trataremos, pois, no próximo tópico, a fragilidade dessa relação nos tempos atuais.

\title{
4.1 A FRAGILIDADE DAS RELAÇÕES NA SOCIEDADE LIQUIDA
}

Antes de compreender o relacionamento na era das redes sociais, é importante identificar o momento o qual a sociedade vivencia. A modernização é o processo de RC: 105265

Disponível em: https://www.nucleodoconhecimento.com.br/comunicacao/olimpiano-digitais 
tornar-se moderno. Não existe um consenso sobre o início da modernidade, no entanto, dois eventos históricos foram decisivos para o estabelecimento dela, são eles: A Revolução Industrial [7]e a Revolução Francesa.[8]

Ambos os acontecimentos trouxeram rompimento com estruturas políticas, sociais, econômicas, pensamentos e as relações sociais anteriores. Bauman (2015) afirmou que a principal característica da modernidade é a de derreter os sólidos, ou seja, as estruturas recebidas pela sociedade tradicional.

Modernidade é precisamente o grau de liquidez. Estou dizendo grau de liquidez, porque toda modernidade foi liquida. Toda modernidade se especializa em derreter os sólidos, em derreter as estruturas recebidas, as formas de vida recebidas e de refazê-las em um molde diferente. (BAUMAN, 2015)

O autor divide ainda a modernidade em duas etapas: Sólida e liquida. Na primeira, a preocupação não se limitava a dissolução dos sólidos recebidos, mas na construção de novos.

O que moveu os pioneiros da modernidade no início do projeto moderno foi a insatisfação com a solidez dos sólidos existentes. Eles acreditavam que não eram sólidos o suficiente, e a verdadeira ordem que iriam construir, a ordem moderna, seria distinta do passado por ser verdadeiramente sólida. $O$ que significa ser verdadeiramente solido? Bem, o que eles queriam dizer, na verdade, é que seria uma sociedade perfeita. (BAUMAN, 2015)

Porém na segunda metade do século $X X$ teria ocorrido um desapontamento com os novos sólidos criados, por exemplo, a incapacidade do mercado em lidar com a desigualdade, entre outros. Paralelo a isso, houve a ocorrência de fenômenos sociais como a globalização e o avanço nas tecnologias da comunicação.

Todas essas profundas transformações levaram alguns pensadores a declararem que a modernidade acabou, e, portanto, vivemos atualmente na pós-modernidade. Bauman, porém, falou que "Pós-modernidade foi, em essência, um termo equivocado.

RC: 105265

Disponível em: https://www.nucleodoconhecimento.com.br/comunicacao/olimpiano-digitais 
Nós não somos pós-modernos, nós somos modernos. Nós somos absolutamente modernos.". (BAUMAN, 2015)

A característica de derreter os sólidos está presente e intensificada. Dessa forma, segundo Bauman (2000), vivemos agora na segunda fase da modernidade, a "modernidade liquida". Em suas palavras, a modernidade liquida seria: "um mundo repleto de sinais confusos, propenso a mudar com rapidez e de forma imprevisível." (BAUMAN, 2003, p. 4).

Por que liquidez? Bem, porque o líquido é notório por não ser capaz de manter a sua forma, a menos que seja forçado artificialmente por um tempo a estar em um recipiente, como um copo, por exemplo. Caso contrário, ele derramaria e vazaria, muda a sua forma o tempo todo. Isto é exatamente o que o nosso mundo é como um todo: ele é líquido. Não podemos confiar que quando saímos para uma viagem e voltamos as coisas vão estar como eram antes, as coisas certamente estarão mudadas, de uma ou de outra maneira. Por isso, eu escolhi a metáfora da liquidez para descrever esta característica distintiva das sociedades em que vivemos. (BAUMAN, 2012)

Nessa modernidade a relação entre os indivíduos não tem mais uma forma rígida e duradoura. Nada é feito para durar, tudo está em uma constante transformação, é efêmero. A liquidez traz uma nova tendência de relacionamento, o relacionamento online. Bauman (2017) diz que as operações de mercado servem de modelo para essas relações entre as pessoas. Ou seja, as relações ganham um caráter de consumo. Pessoas tornam-se substituíveis assim como um produto que não supre mais as necessidades encontradas.

Para melhor explicar a fragilidade do relacionamento na sociedade atual, Bauman (2011) conta sobre o diálogo que teve com um "viciado em Facebook" que se gabou de ter feito 500 amigos em um dia. Com este relato, o filósofo buscou mostrar a mudança na noção de amizade.

Em uma pesquisa realizada pelo "Instituto de Estudos de Comportamentos e Consumo Diário de Campo" (2019) 60\% dos respondentes disseram se sentir RC: 105265

Disponível em: https://www.nucleodoconhecimento.com.br/comunicacao/olimpiano-digitais 
próximos de seus influencers favoritos, e $40 \%$ chegaram a confessar que se sentem amigos deles.

A natureza da identificação, apresentada por Morin, apresenta-se de forma premente na era da cibercultura, porém, essa relação é frágil e líquida como a sociedade atual. Bauman (2011) evidencia que uma rede é mantida viva por duas diferentes atividades, uma é conectar e a outra é desconectar. Dessa forma, a atratividade deste novo tipo de amizade estaria relacionada com a facilidade de desconectar.

De acordo com a mesma pesquisa citada anteriormente, quem cultiva o hábito de seguir influenciadores digitais busca leveza, bem-estar, prazer, e também dicas práticas sobre o que comprar ou aonde ir, por exemplo.

Como já foi comentado no início deste artigo, o consumidor é consciente e ativo, e busca satisfação própria. Os nichos virtuais comandados pelas diversas segmentações de digitais influencers respondem as nossas demandas de desejos. Eles podem satisfazer essas necessidades oferecendo dicas de maquiagem, vida saudável, filme, ou apenas oferendo suas vidas pessoais como entretenimento.

Porém essa relação influenciador-seguidor é frágil e efêmera. A facilidade de desconectar coloca o influenciador em busca de constante aprovação. É preciso inovar, manter-se aos bons olhos do público para que o seu engajamento não despenque, assim como a sua posição capaz de influenciar.

No passado, as grandes celebridades, em sua maioria, tinham certa solidez em sua posição. Não é incomum lembrar de polêmicas que permearam as mídias envolvendo nomes célebres, como exemplo, Michael Jackson e Britney Spears, que ainda hoje mantém o legado de rei e princesa do pop. Atualmente, as falhas não são tão toleradas e são constantemente postas em evidência.

RC: 105265

Disponível em: https://www.nucleodoconhecimento.com.br/comunicacao/olimpiano-digitais 
$\mathrm{Na}$ internet, por exemplo, surgiu a cultura do cancelamento, onde ocorre um boicote a personalidades, sejam famosas ou não. Embora o movimento tenha nascido como um meio de denunciar abusos e injustiças, hoje, adquire um novo significado. $\mathrm{O}$ uso equivocado das palavras, uma opinião controversa, uma inadequação na forma de se expressar e até mesmo o silêncio tornou-se motivo para que indivíduos sofram "sanções" online. (CHIARI et al., 2020). Os influenciadores digitais, por sua enorme presença virtual, estão em constante análise e são passiveis de receberem esses julgamentos. Uma ação, mal interpretado ou não, pode desbancar o influenciador de sua posição.

É fato também que a internet oferece variedade dentro dos seus nichos. Se uma pessoa se interessa por maquiagem, por exemplo, e busca nas redes sociais modelos para tal assunto, encontrará uma gama de ofertas. A pessoa pode, então, criar laços com um influenciador do segmento e preferi-lo a outros, defendendo-o, consumindo sua vida e tornando-se "amiga" dele, mas tão fácil como a relação inicia, pode ser interrompida.

Dessa forma, embora os influenciadores digitais estejam cada vez mais presentes na vida das pessoas, é liquida a sua influência, e, portanto, propensa a mudar.

\section{A SOCIEDADE DO DESEMPENHO}

Após a discussão sobre a modernidade líquida, é válido mencionar outra classificação que a sociedade contemporânea recebeu: a sociedade do desempenho (HAN, 2015), uma contraposição a disciplinar de Foucault[9]. É o momento atual onde a produção deve sempre ser maximizada e o homem torna-se hiperativo e hiper neurótico, uma vez que está sempre em busca de atividades e iniciativas e frustra-se ao não atingilá.

A sociedade disciplinar de Foucault (...) não é mais a sociedade de hoje. Em seu lugar, há muito tempo, entrou uma outra sociedade, a

RC: 105265

Disponível em: https://www.nucleodoconhecimento.com.br/comunicacao/olimpiano-digitais 
saber, uma sociedade de academias de fitness, prédios de escritórios, bancos, aeroportos, shopping centers e laboratórios de genética. A sociedade do século XXI não é mais a sociedade disciplinar, mas uma sociedade de desempenho. (HAN, 2015, p. 14)

Segundo Byung-Chul Han (2015), a necessidade compulsiva de manter-se ativo e em constante produção acabaria por gerar indivíduos cansados física e mentalmente. $\mathrm{O}$ filósofo afirma ainda que cada época possui epidemias próprias e são as patologias neurais que definem o século 21.

Visto a partir da perspectiva patológica, o começo do século XXI não é definido como bacteriológico nem viral, mas neuronal. Doenças neuronais como a depressão, transtorno de déficit de atenção com síndrome de hiperatividade (Tdah), Transtorno de personalidade limítrofe (TPL) ou a Síndrome de Burnout (SB) determinam a paisagem patológica do começo do século XXI. (HAN, 2015, p. 7)

De fato, a época atual é reconhecida pela proliferação das doenças mentais, a depressão, por exemplo, foi considerada o mal do século. Muitos estudiosos buscam entender a razão de tal verdade, e por ser tão presente na vida dos indivíduos atualmente, as redes sociais se tornaram alvo de desconfiança. "Uma das mais antigas abordagens centradas nas ameaças dos impactos que as tecnologias poderiam causar no ser humano, estavam centradas no desenvolvimento social e emocional" (SANCHESs apud LALUEZA; CAMPOS, 2019, p. 2).

Uma pesquisa realizada pela instituição de saúde pública do Reino Unido, Royal Society for Public Health, em parceria com o "Movimento de Saúde Jovem" (2017) diz que as redes sociais podem ser prejudiciais a saúde mental se não forem utilizadas de maneira correta. Ao todo, 1.470 participantes falaram sobre seu envolvimento com as plataformas sociais, e a pesquisa revelou que as taxas de ansiedade e depressão entre os jovens de 14 a 24 anos aumentaram 70\% nos últimos 25 anos.

Han (2015) acredita que é o excesso de positividade o denominador comum para a abundância das patologias neurais. Esse excesso estaria presente em todas as esferas da sociedade, comportando-se como propulsor para os males da alma. $\mathrm{Na}$ RC: 105265

Disponível em: https://www.nucleodoconhecimento.com.br/comunicacao/olimpiano-digitais 
contemporaneidade, portanto, a abundância de discursos que pregam a ação produtiva e a ideia de que todas as metas são alcançáveis, seriam prejudicais para o desenvolvimento do indivíduo.

As redes sociais são um grande palco para isso. É imensurável o número de apelos a "vida perfeita" encontrados nesse canto do ciberespaço. Seja o corpo perfeito, o trabalho ideal ou a viagem dos sonhos, parece que há sempre alguém alcançando aquilo que almejamos para nós.

A pesquisa citada acima indicou que o compartilhamento de fotos pelos Instagram impacta negativamente no sono, na autoimagem e aumenta o medo dos jovens de ficar fora dos acontecimentos. Cerca de $70 \%$ deles disseram que o aplicativo já os fez sentir-se pior em relação a própria autoimagem.

Uma matéria realizada pelo portal Medley (2019) trouxe o depoimento do jovem ex influencer digital Bruno Peres, que disse que ao alcançar 25 mil seguidores, a rede social acabou se tornando um problema, pois ele sentia uma necessidade intensa de agradar essas pessoas e fazer o número de seguidores do Instagram aumentar cada vez mais. Ele declarou ainda que a situação virou um jogo, pois quanto mais seguidores alguém tinha, mais ele era poderoso e poderia ser importante para ajudálo a alavancar o número de seguidores na própria conta.

Visto que são os influenciadores digitais que lidam de perto com estas plataformas e seus impactos, é válido pensar sobre eles. Ao acompanhar um perfil, os seguidores buscam imaginários ideais, modelos para algo que eles próprios gostariam de alcançar, como foi visto na natureza da projeção. Essa positividade pode aparecer em qualquer aspecto, alguns exibem um relacionamento perfeito ou uma vida saudável ou viagens incríveis ou aparência física invejável. Os influenciadores, em especial do Instagram, vivem pela positividade.

RC: 105265

Disponível em: https://www.nucleodoconhecimento.com.br/comunicacao/olimpiano-digitais 
Importante frisar, porém, que o objetivo deste trabalho não é condenar as redes sociais. A intenção é tratar a percepção que os próprios influenciadores digitais têm acerca dela, especialmente no que se refere à proximidade que permitem com os seguidores. Para tanto, analisaremos no tópico seguinte as entrevistas pessoais realizadas com cinco influenciadores digitais do Instagram.

\section{ENTREVISTAS COM INFLUENCIADORES DIGITAIS DO INSTAGRAM}

As entrevistas foram realizadas de forma online com cinco influenciadoras[10] da rede social Instagram, todas produzem conteúdo voltado para o público feminino. Ressalto que as entrevistadas concordaram anteriormente com a temática abordadas e as perguntas feitas, concedendo autorização escrita para o uso das informações fornecidas bem como para a divulgação de seus perfis.

A primeira participante da pesquisa, Kéren, dona do perfil @eukerensalles, possui atualmente 240 mil seguidores e produz conteúdos principalmente voltados para o universo de maquiagem. Já Amanda, @alokadosachados, compartilha dicas de locais onde encontrar roupas e acessórios em um valor acessível, ela conta com 94,5 mil seguidores. Carolina dedica o seu perfil, @entre.amigasz, para falar sobre moda, assim como Giovanna, @giovannacomdoisn, elas possuem 61,8 e 115 mil seguidores, respectivamente. A última participante, Bruna, do perfil @brunadantas.blog, mostra para os seus 46 mil seguidores como é ser uma mãe na moda e bem-informada.

Expostas as informações sobre as entrevistadas, para dar seguimento as análises das entrevistas realizadas, irei me referir aos participantes como: entrevistada um (@eukerensalles), entrevistada dois (@alokdosachados), entrevistada três (@entre.amigasz), entrevistada quatro (brunadantas.blog) e entrevistada cinco (@giovannacomdoisn)

RC: 105265

Disponível em: https://www.nucleodoconhecimento.com.br/comunicacao/olimpiano-digitais 
Após as entrevistas, as gravações em áudio foram transcritas (Apêndice 1). Para análise dos resultados, primeiramente foi feita uma leitura flutuante, ou seja, o contato inicial com o documento e, em seguida, a exploração do material.

Quando perguntadas sobre como iniciaram o trabalho nas redes sociais, as influenciadoras mostraram ter tido um começo semelhante. Iniciaram fazendo postagens despretensiosas e compartilhando sobre temas que as interessavam, e, aos poucos, foram ganhando reconhecimento. O Instagram não foi a plataforma inicial de todas, mas hoje é a que elas mais se dedicam, embora, não a única.

Já sobre as maiores conquistas, podemos perceber que todas consideram as parcerias com grandes marcas uma das principais, além da relação com os seguidores e a capacidade de os influenciar e ajudar.

$\mathrm{Na}$ terceira pergunta, sobre as dificuldades encontradas, as respostas começam a diversificar. A Entrevistada dois falou sobre a própria plataforma como um dos seus maiores desafios, indicando que o Instagram dificulta o alcance conforme 0 crescimento da conta, falou também sobre o preconceito das pessoas com o termo "achados", [11]que lançam sobre ele um olhar pejorativo. Já para a Entrevistada quatro, o maior desafio é a falta de apoio das pessoas próximas que não entendem o trabalho de influenciador digital. A Entrevistada três falou sobre quando foi diagnosticada com câncer e precisou dividir o seu tempo entre o tratamento e a produção de conteúdo. A Entrevistada cinco contou sobre como essa caminhada depende de diversos fatores, e não apenas da sua dedicação. Comentou ainda que é um desafio continuar insistindo sem desanimar, e também o julgamento a que estão expostos. A primeira entrevistada falou também sobre o peso de lidar com a opinião dos outros, além de contar alguns episódios que a afetaram negativamente.

Logo após, elas falaram sobre a pressão relacionada ao contato com os seguidores. Apenas a Entrevistada cinco afirmou não sentir exatamente uma pressão, mas disse

RC: 105265

Disponível em: https://www.nucleodoconhecimento.com.br/comunicacao/olimpiano-digitais 
já ter recebido críticas online. A Entrevistada dois declarou que acredita não receber tanta pressão por evitar compartilhar muito da sua vida pessoal, mas ainda assim, já aconteceu. Entrevistada três acredita que todos que trabalham na internet já passaram por isso em algum momento e a Entrevistada um declarou ficar abismada com como as pessoas afirmam coisas que não condizem com a realidade.

Todas as participantes declararam já terem, em algum momento, apagado ou arquivado uma postagem. Seja por não ter recebido o retorno esperado, por comentários negativos ou para desvincular a sua imagem de algum produto. Elas também disseram sentir pressão para postar frequentemente, algumas encontram essa pressão nelas próprias, outras vindas do próprio Instagram, uma vez que ao não postar com frequência isso acaba por gerar uma queda no engajamento.

Em relação ao tempo diário, foi a Entrevistada três que afirmou gastar menos tempo online, cerca de cinco ou seis horas. As Entrevistadas um e cinco apontaram dedicar todo o dia para as redes.

Sobre desistir, as Entrevistadas um, três e cinco disseram já pensar na possibilidade mais de uma vez, já as demais, mesmo com todas as dificuldades, afirmaram gostar o suficiente para não considerar essa hipótese.

Quando questionadas sobre receber comentários maldosos e negativos todas disseram já passar pela situação ao menos uma vez. Elas falaram sobre como as pessoas não sabem se expressar e por terem opiniões diferentes acabam por ofendêlas. Foi possível notar como algumas delas ficam "mexidas" com o assunto.

As opiniões também foram unânimes quando questionadas sobre o desejo de crescer ainda mais. Embora gratas por tudo o que conquistaram, elas mostraram-se insatisfeitas.

RC: 105265

Disponível em: https://www.nucleodoconhecimento.com.br/comunicacao/olimpiano-digitais 
Por último, foi questionado o poder dos comentários negativos sobre essas influenciadoras. As Entrevistadas dois e três disseram tentar focar sempre no saldo positivo, embora afirmaram já terem sentindo-se afetadas algumas vezes. Entrevistada um e cinco contaram que sofrem muito com isso e ligam demais para as opiniões.

Podemos observar algumas das questões tratadas neste trabalho. As redes sociais de fato estão cada vez mais presentes na vida dos indivíduos. O Instagram cresce velozmente e foi citado mais de uma vez durante a entrevista uma migração para essa plataforma, e assim sendo, cada vez mais os próprios influenciadores voltaram-se para ela.

Ao lidar com as redes sociais, as entrevistadas colocam sobre si certa pressão, e entendem a importância de sempre fazer-se presente online, uma vez que o fluxo na internet é continuo, e, portanto, para serem vistas, precisam de dedicação diária. As efemeridade e constante mudança da sociedade, pensada na perspectiva da liquidez de Bauman (2015), é ainda mais forte nos ambientes virtuais. Ganhar ou perder seguidores, e consequente influência e engajamento, é ação que pode ocorrer em poucos segundos.

Os seguidores buscam através destes perfis conteúdos que agradem as suas vontades, e, como foi possível perceber, muitas vezes revoltam-se quando isso não acontece em algum momento. A constante busca pela satisfação própria, mencionada no tópico 1.1, acarreta nisso. Ao estarem presos em suas bolhas sociais (JÚNIOR; PELLIZARI, 2019), as opiniões controversas muitas vezes podem ser rejeitadas e acabarem por gerar os comentários negativos.

Certamente, as redes também trazem alegrias para estas influenciadoras, que se dedicaram a falar sobre o carinho dos seguidores que se inspiram nelas e tornam as suas opiniões capazes de influenciá-los.

RC: 105265

Disponível em: https://www.nucleodoconhecimento.com.br/comunicacao/olimpiano-digitais 
Os influenciadores digitais são produtos das redes sociais e, portanto, interferem diretamente nela, mas também sofrem essa interferência, como foi possível perceber através da opinião das cinco influenciadoras entrevistadas.

\section{CONSIDERAÇÕES FINAIS}

Pesquisas realizadas pela Global Weblndex (2019) atestam que o tempo diário médio que cada pessoa dedica a sites ou aplicativos de mídia social aumentou significativamente nos últimos anos. Por terem as redes sociais como fonte de trabalho, real ou almejada, os influenciadores marcam presença nesse ambiente virtual mais do que usuários comuns. Foi possível observar através das entrevistas que chegam a dedicar 24 horas diárias a elas.

O excesso de dedicação, porém, não é irrelevante. Sendo a modernidade propensa a mudar com rapidez e de forma imprevisível (BAUMAN, 2003), conquistar e manter o status de "fama" adquirido na internet, são ações distantes uma da outra. Bauman (2017) afirma que a vida líquida é uma sucessão de reinícios, e precisamente por isso é que os finais rápidos e indolores tendem a ser os momentos mais desafiadores e as dores de cabeça mais inquietantes.

Os influenciadores buscam evitar estes finais. Porém uma vez que o relacionamento na sociedade atual não seja feito para durar (BAUMAN, 2017), aquele baseado no mundo virtual é ainda mais inconstante.

Tratando agora sobre a pergunta norteadora desta pesquisa, as informações coletadas nas entrevistas serão cruzadas com os estudos expostos em cada tópico anterior. Visto tudo o que foi citado, é válido afirmar que os influencers trazem, portanto, percepção dúbia em relação ao contato com público. Inegável que sentem gratidão por seus seguidores, mas sofrem constantemente com a pressão de agradar e com os ataques quando não o fazem. Encontram-se em constante pressão para inovar seus conteúdos e a eles próprios no intuito de não entediar os seguidores, que RC: 105265

Disponível em: https://www.nucleodoconhecimento.com.br/comunicacao/olimpiano-digitais 
são conscientes e tendem a permanecer apenas onde sentem-se representados ou agradados.

O feedback imediato e constante permitido pelas redes apresenta duas facetas, a positiva e a negativa. Foi perceptível que o carinho, a admiração e apoio dos seguidores agradavam as influenciadoras entrevistadas, e também eram almejados por elas. Entretanto, o lado negativo destes comentários mostrou-se capaz de influenciar e abalar as mesmas. Algumas vezes, levando-as a pensar em desistir.

As plataformas sociais de relacionamento mostram-se como propulsoras para alguns problemas observados, por exemplo, por Bauman (2011) e Han (2015), porém, elas nada mais são do que uma amplificação de comportamentos humanos que ocorrem desde os primórdios.

A ausência de saúde mental está relacionada a incapacidade de harmonizar as emoções, e, dessa forma, podem desencadear as doenças neurais que determinam a paisagem patológica do começo do século XXI (HAN, 2015). Portanto o mal não seria as redes sociais em si, mas o não saber lidar com os sentimentos que são alcançados através dela.

Uma vez que as redes sociais são uma das formas de comunicação mais importantes atualmente, embora tendam a se inovar, não é possível, no contexto em que vivemos, enxergar um fim para elas, portanto, é importante encontrar meios de melhor lidar com essa forma de interação.

Com o intuito de proteger a autoestima dos usuários, em julho de 2019, o Instagram retirou as curtidas da plataforma. A medida desagradou alguns influenciadores e empresas, mas de acordo com o Instagram, a mudança foi feita pensando nos usuários, e não neles. A decisão busca fazer da rede social um local menos tóxico (SALGADO; CASTRO, 2019).

RC: 105265

Disponível em: https://www.nucleodoconhecimento.com.br/comunicacao/olimpiano-digitais 
Entretanto é válido mencionar que os influenciadores digitais são usuários do aplicativo. Algumas entrevistadas mencionaram que a plataforma acaba por dificultar o engajamento e crescimento delas, além de transmitir certa pressão em estar constantemente criando conteúdos. Visto que, o engajamento cai ao não postar com frequência. Ou seja, o próprio aplicativo contribui para o sentimento de precisar estar sempre produzindo, como é característico da sociedade do desempenho (HAN, 2015)

Portanto, embora já seja possível ver uma preocupação com o uso das redes em relação aos usuários comuns, ainda não há o mesmo cuidado para os influenciadores. Desse modo, esse estudo objetivou lançar luz sobre os indivíduos que mais se fazem presentes nelas, e, portanto, estão propensos às consequências disso e visa, futuramente, auxiliar novos estudos que abordem o tema. Buscando alcançar um melhor entendimento sobre como proteger a mente daqueles que estão tão expostos aos julgamentos na reconhecida "terra sem lei" que é a internet. Afinal, ela não irá embora e trata-se de nossa responsabilidade colaborar para um uso saudável das tecnologias que nos cercam, nos modificam e são modificadas por nós.

\section{REFERÊNCIAS}

AS REDES sociais além do like. [S. I.], 7 out. 2015. Medley. Disponível em: $<$ https://<www.medley.com.br/blog/saude-mental/setembro-amarelo.> Acesso em: 6 set. 2020.

BAUMAN, Zygmunt. Modernidade Liquida. Rio de Janeiro: Jorge Zahar, 2001.

BRASIL é $2^{\circ}$ em ranking de países que passam mais tempo em redes sociais [S. I.], 6 set. 2019. Época Negócios. Disponível em: $<$ https://epocanegocios.globo.com/Tecnologia/noticia/2019/09/brasil-e- 2-em-rankingde-paises-que-passam-mais-tempo-em-redes-sociais.html.> Acesso em: 15 jul. 2020

RC: 105265

Disponível em: https://www.nucleodoconhecimento.com.br/comunicacao/olimpiano-digitais 
DEPRESSÃO, a doença do século xxi. [S. I.], 3 out. 2014. Carta Capital. Disponível em: <https://www.cartacapital.com.br/educacao/a-doenca-do\%E2\%80\%A8-seculoxxi/.> Acesso em: 27 ago. 2020.

ENTREVISTA exclusiva Zygmunt Bauman. Youtube, 28 nov. 2011. Núcleo de Pesquisa em Estudos Culturais Npec. Disponível em: <https://www.youtube.com/watch?v=1 miAVUQhdwM\&t=78s.> Acesso em: 6 jul. 2020 FRONTEIRAS do Pensamento. Zygmunt Bauman - A amizade Facebook. Youtube, 18 fev. 2013. Disponível em: <https://www.youtube.com/watch?v=5Lm2O3Q56Wg.> Acesso em: 6 jul. 2020.

GIBSON, William. Neuromancer. Brasil: Editora Aleph, 2016

HAN, Byung Chul. Sociedade do cansaço. 1. ed. Brasil: Editora Vozes, 2010.

LÉVY, Pierre. A Revolução Contemporânea Em Matéria De Comunicação. Tradução: Juremir Machado da Silva. Famecos, Porto Alegre, no 9. p. 37 - 49, dez. 1998.

LEVY, Pierre. Internet E Desenvolvimento Humano. Cad. psicopedag., São Paulo v. $\quad 5, \mathrm{n} . \quad 9,2005 \quad$.Disponível em:

<http://pepsic.bvsalud.org/scielo.php?script=sci_arttext\&pid=S1676$10492005000100008 \&$ Ing=pt\&nrm=iso >. Acesso em 06 nov. 2020.

MALAR, João Pedro. Redes Sociais: 43\% Dos Internautas Dizem Ter Vício Em Seguir Influenciadores. [S. $\quad$ I.], 17 dez. 2019. Estadão. Disponível em: $<$ https://emais.estadao.com.br/noticias/comportamento,redes-sociais-43-dosinternautas-dizem- ter-vicio-em-seguir-influenciadores,70003129159.> Acesso em: 1 set. 2020.

MOREIRA, Helen; PATRIOTA, Karla Regina Macena. O Uso da Internet para Criar Interação, Relacionamento e Experiência com a Marca. Intercom. Caxias do Sul, v. RC: 105265

Disponível em: https://www.nucleodoconhecimento.com.br/comunicacao/olimpiano-digitais 
XXXIII, 2010. Disponível em: <https://docplayer.com.br/51317065-O-uso-da-internetpara-criar-interacao-relacionamento-e-experiencias-com-a-marca-1.html> Acesso em: 05 set 2020

MOREIRA, Thays; RIOS, Riverson. A contrução da Celebridade Midiática no Contexto dos Digital Influencers. Intercom. São Paulo, v. XXXIX, 2016. Disponível em $<$ https://portalintercom.org.br/anais/nacional2016/resumos/R11-2488-1.pdf> Acesso em: 05 set 2020

PAVLÍK, John; MOREIRA, Sonia Virgínia. O Impacto das Tecnologias da Informação na Prática do Jornalismo. São Paulo: Revista Brasileira de Ciências da Comunicação, Volume XXIII, nº 1, janeiro/julho de 2000.

PELLIZZARI, Bruno Henrique Miniuchi; JUNIOR, Irineu Francisco Barreto. Bolhas Sociais e seus efeitos na Sociedade da Informação: Ditadura do Algoritomo e Entropia na Internet. Revista de Direito, Governança e Novas Tecnologias, [s. I.], $7 \mathrm{dez}$. 2019. Disponível em: <https://indexlaw.org/index.php/revistadgnt/article/view/5856>. Acesso em: 14 nov 2020

RECUERO, Raquel. Redes Sociais na Internet. [S. I.]: Editora Sulina, 2008.

SABINO, Eduardo; TERRA, Helena; MENEZES, Roberto. Retratos da Vida Líquida em Três Textos da Narrativa Brasileira Contemporânea. CES Revista. Juiz de Fora, $2017 . \quad$ Disponível em: $<$ https://seer.cesjf.br/index.php/cesRevista/article/view/1145/788> Acesso em: 19 ago. 2020

SALGADO, Daniel; CASTRO, Rodrigo. Não deu Like: Instagram Elimina Curtidas para Proteger Autoestima de Usuário. [S. I.], 17 jul. 2019. Época. Disponível em: $<$ https://epoca.globo.com/sociedade/nao-deu-like-instagram-elimina-curtidas-paraprotegerautoestima-de-usuario-23814995>. Acesso em: 25 nov. 2020.

RC: 105265

Disponível em: https://www.nucleodoconhecimento.com.br/comunicacao/olimpiano-digitais 
SANCHES, Paula da Fonte; FORTE, Cleberson Eugênio. Redes Sociais e Depressão: Um Estudo Estatístico sobre a Percepção de Bem-estar em Estudantes Universitários. Revista Tecnológica da Fatec Americana [s. l.], vol. 07, n. 02, abril/setembro de 2019.

$<$ http://ric.cps.sp.gov.br/bitstream/123456789/4381/1/Artigo\%20\%20Paula\%20da\%2 OFonte\%20Sanches.pdf>. Acesso em: 10 nov. 2020

SANTAELLA, Lucia Da Cultura das Mídias à Cibercultura: O Advento do Póshumano. Revista FAMECOS, v. 10, n. 22, p. 23-32, 12 abr. 2008. Disponível em: $<$ https://revistaseletronicas.pucrs.br/ojs/index.php/revistafamecos/article/view/3229/2 49> Acesso em: 02 out 2020

SILVA, Cristiane Rubim Manzina; TESSAROLO, Felipe Maciel. Influenciadores Digitais e as Redes Sociais Enquanto Plataformas de Mídia. Intercom. São Paulo, v. XXXIX, 2016.

em: $<$ https://portalintercom.org.br/anais/nacional2016/resumos/R11-2104-1.pdf>. Acesso em: 4 ago. 2020

SIMAS, Danielle Costa de Souza; JÚNIOR, Albefredo Melo de Souza. Sociedade em Rede: Os Influencers Digitais e a Publicidade Oculta nas Redes Sociais. Revista de Direito, Governança e Novas Tecnologias, [s. I.], 2018. Disponível em: $<$ https://www.indexlaw.org/index.php/revistadgnt/article/view/4149/pdf>. Acesso em: 4 ago. 2020

SIMÕES, Isabella de Araújo Garcia. A Sociedade em Rede e a Cibercultura: dialogando com o pensamento de Manuel Castells e de Pierre Lévy na era das novas tecnologias de comunicação, 2009, [S. l.], Disponível em: $<$ https://cursosextensao.usp.br/pluginfile.php/52266/mod_resource/content/1/Socied ade_Cibercul tura.pdf. $>$. Acesso em: 18 set. 2020

RC: 105265

Disponível em: https://www.nucleodoconhecimento.com.br/comunicacao/olimpiano-digitais 
SOCIAL Media Trends 2018: panorama das empresas e usuários nas redes sociais [S. I.], 6 dez. 2018. Inteligência corporativa rock contente. Disponível em: $<$ https://inteligencia.rockcontent.com/social-media-trends-2018/.> Acesso em: 17 set. 2020.

VILICIC, Felipe. Conheça a história do brasileiro que criou o Instagram. [S. I.], 7 out. 2015. Exame. Disponível em: <https://exame.com/tecnologia/conheca-a-historia-dobrasileiro-que- criou-o-instagram/.> Acesso em: 14 set. 2020.

WIMMER, Juliane; GREGGIANIN, Mônica. Influenciadores Digitais: Um Estudo De Caso Sobre O Perfil De Gabriela Pugliesi No Instagram. 2018, Faculdades Integradas de Taquara, Rio de Janeiro.

WOLF, Mauro. A teoria hipodérmica. In: WOLF, Mauro. Teorias Da Comunicação: Mass Media: Contextos E Paradigmas Novas Tendências Efeitos A Longo Prazo O Newsmaking. 8. ed. Lisboa: EDITORIAL PRESENÇA, 1999. cap. 1.2, p. 22-23.

\section{APÊNDICE I - ENTREVISTAS TRANSCRITAS}

Pergunta 1 - Como começou a sua história como influenciadora?

Entrevistada um: Bom, então, tudo começou no Snapchat. Eu já tinha Instagram, né? Não lembro se existia a plataforma do Instagram na época, mas eu já postava foto, usava o Facebook, usava as redes sociais. E aí tinha o Snapchat e eu fazia muitos stories lá. Eu não lembro se chamava stories mesmo, né? Mas eu fazia muitos vídeos lá no Snap e aí a galera pedia para eu fazer vídeos no Youtube. Era a época do Vine, Snap, Youtube... e aí eu migrei para o Youtube também. Eu fiz mil inscritos muito rápido no Youtube. As pessoas gostavam muito. E aí o meu telefone quebrou, alguma coisa assim aconteceu e eu parei e depois de muito tempo voltei. Até tem vários vídeos no Youtube de mim falando "Gente, estava sem celular a 3 meses" ... Aí depois começou a galera a ir todo mundo para o Instagram. E aí o Snapchat foi morrendo, foi

RC: 105265

Disponível em: https://www.nucleodoconhecimento.com.br/comunicacao/olimpiano-digitais 
morrendo, foi morrendo. E aí todo mundo migrando para o Instagram, eu migrei também. Só que no início eu postava só foto e continuava com o Youtube, mas aí toda hora o meu telefone dava piti, a minha câmera pifava... Daí eu comecei a ir fazendo alguns videozinhos, mas eu apagava porque tinha vergonha. Porque não ficava do jeito que eu queria, não tinha uma edição boa, uma resolução boa. Aí toda hora eu vivia apagando e postando, apagando e postando. Aí eu postava mais fotos, tipo Tumblr, sabe? Então, eu comecei assim. Aí eu fazia o store direto né, diariamente. $\mathrm{E}$ aí até então eu parei com o Youtube e só fiquei com o Instagram Isso tem uns cinco anos que começou. E aí do ano passado para cá... ano passado eu comecei a fazer vídeos com frequência, comprei um telefone bom. E aí de setembro para cá que as coisas começaram a acontecer de verdade, entendeu? Eu tinha em setembro... eu demorei muito para fazer $10 \mathrm{~K}$ no Instagram. Em setembro eu tinha 13 mil e hoje eu estou 47 acho. Então tipo assim, de setembro para cá que foi muito rápido, disparou muito rápido. Mas acho que é basicamente assim que começou.

Entrevistada dois: Então, eu sempre gostei muito de acompanhar perfis de achados, mas na época que eu comecei até que não tinham muitos. Essa questão também de compartilhar as dicas, os preços remarcados, promoções...sempre gostei muito de acompanhar. Aí decidi criar o meu, né? E foi uma coisa sem pretensão. Eu fui desenvolvendo o meu trabalho, fui aprendendo... fui aprendendo meio que sozinha, porque eu não entendia muito né, como funcionava. E fui desenvolvendo, fui conhecendo o meu público, fui vendo o que eles gostavam que eu postasse, o que não gostava, e tudo mais. E fui crescendo... e fui conseguindo parcerias e tudo o mais. Nunca tive pretensão de "ah, vou ser uma influencer, vou querer ficar conhecida.". Não, nunca foi isso. Eu sempre quis mesmo compartilhar dicas de alguma coisa que eu gosto, tanto que eu acho que foi isso que me ajudou a crescer. Eu sempre fiz tudo porque eu gosto de fazer e não por ter um objetivo de querer crescer e ficar famosa... Não que eu seja famosa, mas estou dizendo assim, eu sempre fiz por gostar mesmo, não como uma obrigação. E é isso.

RC: 105265

Disponível em: https://www.nucleodoconhecimento.com.br/comunicacao/olimpiano-digitais 
Entrevistada três: Então, Larissa, eu sempre gostei muito de moda e eu sempre procurei comprar peças que fossem tendência, só que estivessem também no meu orçamento que sempre foi muito baixo. $E$ todas as vezes que eu usava essas peças alguém me perguntava onde eu comprei. Eu sempre falei, né? Eu passava informação de onde era, nunca tive essa coisa de guardar assim para mim, sempre fui muito franca em falar. Aí eu resolvi criar né, uma página no Facebook na época para postar as minhas fotos e onde eu comprava as coisas para ficar mais fácil. Nisso acabou que eu fiquei um ano aí postando as coisas e do nada começou a estourar, veio chegando mais pessoas... porque eu postava não só o que eu comprei, mas também o que eu via na rua. Do meu gosto, claro. Aí acabou que foi crescendo. Uma amiga indicando para a outra e quando eu vi, tive que migrar para o Instagram, né? Porque teve essa transição de Facebook para o Instagram. Aí eu comecei a postar lá também, acabou que lá também deu certo. E hoje estamos aí.

Entrevistada quatro: Então, a minha história como influenciadora começou há dois anos atrás, quando a minha filha nasceu, dois anos e meio atrás quando a minha filha nasceu. Eu comecei a compartilhar a minha rotina pós maternidade, né? EU já tinha um perfil pessoal, né? Esse perfil já tinha uma quantidade boa de pessoas e aí eu comecei a compartilhar e falar nos stories, mas na verdade, desde muito nova eu já tinha o sonho de trabalhar com isso. Tanto que com 14 anos eu já tinha um blog, na época era blog. E aí eu fazia resenha de produtos e tal, só que eu tinha muita vergonha, então assim, não foi para frente, né? Chegou um determinado momento que eu desisti e não foi para frente, mas sempre teve no meu coração essa vontade. Aí depois do nascimento da minha filha comecei a compartilhar e trocar experiencia e comecei a atrair mães e mulheres que estavam passando pelos mesmos problemas, pelo mesmo período e a gente começou a criar uma rede, e foi aí que eu comecei a tratar isso de forma mais profissional.

Entrevistada cinco: Então, a minha carreira de influenciadora, né? A minha história de influenciadora começou muito sem querer, eu sempre gostei muito de gravar vídeos RC: 105265

Disponível em: https://www.nucleodoconhecimento.com.br/comunicacao/olimpiano-digitais 
e tirar fotos, mas sempre foi algo como um hobbie, que eu fazia de vez em quando, sem muito compromisso, sem o dever de sempre estar ali e sem pretensão de que isso fosse me levar em algum lugar. Era uma coisa mesmo para passar o tempo, uma coisa que eu gostava de fazer. E aí eu comecei a postar umas fotos um pouco mais sensual, para um lado um pouco mais sensual, porém, ainda romântico com o meu, na época, namorado, que agora meu marido. E conforme eu fui postando essas fotos e a galera começou a gostar de ver, começou a curtir, comentar, compartilhar muito, marcar usuários. E aí foi quando eu comecei a ganhar um número bom de seguidores. E aí quando eu estava lá com 12,13K marcas começaram a me procurar para mandar mimos, para fechar a divulgação. E aí foi que eu percebi que talvez aquilo ali poderia dar em alguma coisa, poderia chegar em lugar. E aí quando eu já estava com uns 20k mais ou menos, foi quando eu comecei a fazer a coisa se tornar mais profissional, a ter mais compromisso, a trazer outros tipos de conteúdo. A trazer um conteúdo que fosse fazer mais diferença na vida da pessoa... que tipo assim, fosse trazer algum conhecimento para ela ao invés de só trazer foto, sabe? E aí foi que as coisas começaram a fluir. Foi mais ou menos assim que começou, de uma maneira meio que sem querer.

Pergunta 2 - Quais foram as suas maiores conquistas?

Entrevistada um: Bom, a primeira coisa que marcou foi quando eu fiz os meus mil inscritos no Youtube. Eu até dei uma festa! Eu aluguei um salão e aí meus amigos cada um levou um prato. Foram algumas inscritas minhas, minhas seguidoras. Eu fiz sorteio para as minhas seguidoras irem, foram dez meninas. Isso me marcou muito. Eu chorei... enfim. Depois, quando eu estava no Instagram os meus $10 \mathrm{~K}$ foi um milagre para mim. E esse ano as parcerias que eu estou conseguindo. Parcerias grandes, né? No caso marcas grandes: Maybelline, Riachuelo, entre outras marcas. Mas é porque eu fiquei chocada demais quando eu recebi essas propostas.

RC: 105265

Disponível em: https://www.nucleodoconhecimento.com.br/comunicacao/olimpiano-digitais 
Entrevistada dois: Minhas maiores conquistas? Olha, eu tive várias conquistas assim ao longo dos meus anos no Instagram. Mas assim, sem dúvidas nenhuma o alcance que eu tenho, que eu posso ajudar várias pessoas. No começo, as minhas divulgações eram por permuta né. Até hoje eu faço divulgação também por permuta, mas eu consigo também ganhar um dinheiro com a divulgação, com a parceria. Mas eu também consigo ajudar muita gente a encontrar coisas que elas precisam. E elas compras as coisas que eu indico. Então eu fico também muito feliz e impressionada com isso. É uma responsabilidade muito grande, mas é muito legal você ter esse reconhecimento de que você ajudou a pessoa a encontrar o que ela queria, a comprar mais barato e tudo mais. Conheci muita gente legal... Acho que uma das maiores conquistas também, os seguidores ne, eles vem e ficam porque eles querem. Então isso me ajuda também a crescer e eu fico muito feliz que eles gostem do meu trabalho. E repassam para outras pessoas também. Então isso também é um ponto muito positivo e eu considero também uma conquista. Além de fechar parcerias com lojas, com shoppings, também é muito legal porque dá um retorno do meu trabalho. Então, isso só mostra o meu crescimento né, então, isso para mim é uma conquista. Tudo isso né, engloba.

Entrevistada três: Assim, a minha maior conquista e primeira foi essa comunidade de pessoas me seguindo, né? Consumindo o meu conteúdo. A segunda foram as parcerias, no caso os trabalhos que eu conquistei através disso. As marcas que me notaram que eu nunca imaginei tipo Sonho dos pés, Mcdonalds e outras marcas também que eu sempre gostei muito e que eu pude trabalhar.

Entrevistada quatro: As minhas maiores conquistas nessa jornada foram trabalhar com empresas grandes, empresas e marcas conceituadas, né? Recentemente eu fiz um trabalho para uma rede grande de supermercados, sempre estou fazendo trabalho para alguma marca conceituada, uma marca grande no mercado. E aí eu fico muito feliz quando o meu trabalho é reconhecido assim dessa forma.

RC: 105265

Disponível em: https://www.nucleodoconhecimento.com.br/comunicacao/olimpiano-digitais 
Entrevistada cinco: Acho que as maiores conquistas é você fechar publicidade com marcas que você admira muito. Isso é muito legal, é uma grande conquista quando uma marca que eu gosto muito, uma marca grande vem até mim querendo o meu trabalho e também esse carinho que você recebe das pessoas que te acompanham. É um pouco louco você imaginar que tem tipo quase em mil pessoas te acompanhando ali, que elas gostam de você, que elas querem saber da sua vida... tirando alguns casos, né? Mas em sua grande maioria, elas têm um carinho muito legal. Então o que me marcou muito é isso. É esse carinho, é essa troca, é eu sair em algum lugar e alguém me reconhecer e falar que gosta muito do meu trabalho. Isso me marca muito porque me faz sentir capaz, me faz sentir... não é poderosa, mas amadas, sabe? Faz eu me sentir especial. Então, eu acho que uma coisa que me marca muito é esse reconhecimento das marcas e das pessoas que me seguem que gostam do meu trabalho.

Pergunta 3 - Quais foram os seus maiores desafios?

Entrevistada um: Os pontos negativos sempre foram os comentários negativos mesmo. Eu sofri muito hater... não é hater, né? Eu sofri muito comentário negativo na internet. Eu fui parar em site de fofoca e isso trouxe muita coisa ruim para mim. Gente falando da minha pele, gente falando do meu jeito. Isso até hoje dói um pouquinho, mas hoje eu consigo lidar um pouquinho melhor. Eu acho que isso é o ponto pior, não é nem pontos negativos, é o pior ponto. E passa mesmo diariamente, né? Isso mexe um pouco comigo as vezes, mas acho que é isso. E também, a gente fica muito... como é que fala?... as pessoas querem usar muito, sabe? Se aproximam para poder usar, para querer divulgação, não respeita o trabalho, ... Isso também é muito ruim, a falsidade.

Entrevistada dois: Olha, os desafios... acho que um dos desafios maiores é o próprio Instagram. No começo é tudo legal, mas depois ele vai meio que te cobrando as coisas. Ele não libera as publicações para todo mundo, não é todo mundo que vê, não

RC: 105265

Disponível em: https://www.nucleodoconhecimento.com.br/comunicacao/olimpiano-digitais 
é todo mundo que interage. Tem essa questão também do próprio Instagram ficar contra a gente, contra o nosso trabalho, mas não digo nem só o pessoal de achados, mas acho que as pessoas que trabalham com o Instagram enfrentam isso. $E$ também a questão do preconceito com a palavra achados, as meninas de achados. Às vezes as pessoas olham um lado pejorativo, não dando muito valor para o trabalho das meninas de achados. Até mesmo na questão de fechar parcerias, as vezes não fecham porque tem o nome achados, mas se tiver outro nome vai fechar, entendeu? Então acho que isso foi um dos maiores... eu não tive muitos problemas com isso, mas eu já reparei isso. Já teve situação que isso aconteceu, de não conseguir fechar parceria por ter o nome ali de achados e tudo mais. E esse reconhecimento as vezes as pessoas têm um preconceito com o pessoal de achados. Eu olho algumas situações desse jeito. E nessa questão também do Instagram não liberar o alcance, é bem chato mesmo.

Entrevistada três: Assim, eu acho que o maior desafio foi quando eu fiquei doente, né? No caso quando eu fui diagnosticada com câncer e aí eu fiquei naquela coisa de ter que fazer todo o tratamento e ter que me dedicar de outra forma para produzir conteúdo porque... ainda mais com esse negócio de quarentena também, a gente teve que se reinventar, produzir tudo em casa. Então, foi um grande desafio.

Entrevistada quatro: O maior desafio é a falta de poio das pessoas que estão próximas, né? Por ser uma profissão nova, os familiares não entendem muito bem quando a gente fala que trabalha como influenciadora digital, não entendem bem como isso pode dar dinheiro, como funciona o trabalho em si mesmo, né. E essa falta de apoio é uma dificuldade muito grande para quem opta por essa área.

Entrevistada cinco: Os desafios são muitos. É uma caminhada longa, é uma caminhada cansativa, é uma caminhada que você se compara e se cobra muito. É uma coisa que não depende exclusivamente da gente. Tipo, a gente pode estar ali produzindo, mas depende da ferramenta entregar, depende das pessoas gostarem.

RC: 105265

Disponível em: https://www.nucleodoconhecimento.com.br/comunicacao/olimpiano-digitais 
Então, um ponto negativo ou um desafio é isso, é você conseguir estar ali insistindo nos seus sonhos sem você desanimar, sem você se cobrar, sem você se comparar. Isso que é o grande desafio, você não viver numa eterna comparação. A partir do momento que você trabalha na internet... não trabalhando da internet, você já se compara muito com o que você vê por aí, trabalhando você se compara ainda mais. Você se cobra ainda mais. Então isso é complicado. E também o julgamento, entendeu? Quando você começa, das pessoas desacreditando, pessoas próximas de você falando que aquilo não vai dar em nada, as pessoas que te zoam. Então assim, o grande desafio eu acho que é você lidar com a opinião dos outros, né? Com as críticas dos outros. Porque as pessoas brincam mesmo... brincam na verdade te zoando, né? Zoam mesmo, criticam mesmo. E você lidar com as suas próprias críticas e as suas próprias comparações.

Pergunta 4 - Você já sentiu alguma pressão por esse contato tão próximo que você tem com seus seguidores através das redes sociais?

Entrevistada um: Com certeza. As pessoas vêm mesmo com comentários negativos e falando coisas que nem sabem da gente. Eu fico muito abismada com isso. Vem com uma certeza, falando coisas assim que nem é a nossa realidade.

Entrevistada dois: Já sim. Mas nada muito forte. Até porque eu não gosto e nunca gostei de compartilhar muito a minha vida pessoal no Instagram de achados. Desde o começo eu sou assim, no começo o Instagram nem era a minha foto, era uma foto de uma logo, depois que eu mudei. E eu sempre tive essa questão de tomar cuidado das coisas de colocar ali, sempre tentei separar muito. Mas eu sei que eu tenho que aparecer para poder criar uma identidade com os seguidores, mas eu não coloco muitas coisas da minha vida ali, até mesmo para evitar isso. Tem algumas seguidoras que são muito sem noção, mas assim, se comenta alguma coisa que eu não gosto, eu não discuto. Eu vou lá e bloqueio a pessoa, não vai ver nunca mais e tchau. Mas nunca precisei me exaltar e ficar nessa questão não. Acho que a cobrança não vem

RC: 105265

Disponível em: https://www.nucleodoconhecimento.com.br/comunicacao/olimpiano-digitais 
tanto porque eu não exponho muito da minha vida no Instagram ali dos achados. O meu foco mesmo é postar os achados e falar alguma coisa ou outra. Então eu não sinto muito essa pressão, mas alguns seguidores né... a gente até releva.

Entrevistada três: Sim, eu acho que todo mundo que trabalha com internet já passou por isso. Até porque a gente expõe a nossa intimidade, fica disponível para as pessoas e algumas pessoas confundem isso com liberdade e acabam pressionando de alguma forma. Graças a Deus eu passei por isso poucas vezes assim, mas acho que nenhum ser humano é perfeito então as vezes a gente comete isso de pressionar outra pessoa. Mas eu creio que essa é a intenção também, é mais por esse excesso de informação, de liberdade, disponibilidade.

Entrevistada quatro: Sim, com certeza. Mas eu acredito que ter opiniões diferentes é normal, né? O que já não é normal é quando isso passa a ser um desrespeito, um xingamento, e mesmo assim as pessoas fazem isso. Então, eu já passei por isso sim, mas eu tento me manter autêntica e manter as minhas opiniões, né? Tanto que assim, eu aproximo as pessoas que pensam parecido comigo, que tem uma opinião parecida, porque a pessoa que não se identifica, ela nem vai me seguir, né? Então assim, eu tento manter a minha essência sem me deixar abater por isso, sem me deixar ser impactada por isso. Se eu vejo a grande quantidade de comentários positivos, de feedbacks positivos que eu recebo então assim, eu tento não focar nesses comentários negativos, sabe?

Entrevistada cinco: Então, pressão assim não. Uma pressão assim não. Já tive críticas e tals, mas acho que não uma pressão, pressão, pressão... Sempre tem uma pessoa ou outra que vem e cobra alguma coisa de você falar ou de você se posicionar sobre. Mas eu nunca me senti pressionada. Nunca me passou esse sentimento de ser ou de estar sendo pressionada

RC: 105265

Disponível em: https://www.nucleodoconhecimento.com.br/comunicacao/olimpiano-digitais 
Pergunta 5 - Já aconteceu de você postar algo que inicialmente tinha gostado, mas aí não teve muitas curtidas, nem comentários ou até teve, mas foram comentários negativos e você acabou apagando a postagem?

Entrevistada um: Teve sim uma postagem, que eu me lembre agora. Foi até a postagem do Prior, eu postei e aí... eu postei por causa da música, né? Para me trazer engajamento porque era o assunto do momento. Daí veio muita gente caindo em cima de mim e dizendo que eu estava a favor do machista e bla bla bla. Aí eu acabei arquivando. Eu arquivei a publicação porque tinham muitos comentários e aí não me fez bem. E aí depois disso teve a música da Luíza Sonza com o Vitão, eu postei né porque era o assunto do momento, eu postei porque aquilo ia me dar um retorno bom. E aí teve comentários ruins. Eu não apaguei esse vídeo, eu fiz ao contrário, eu não apaguei o vídeo. Eu cheguei a apagar alguns comentários e respondi outros, mas bem de boas mesmo.

Entrevistada dois: Ah, com certeza já arquivei bastante fotos que não tiveram o retorno que eu esperava. Mas nem digo de curtida assim, é porque realmente o alcance não atingiu as pessoas para poder o pessoal curtir. Mas sim, isso acontece muito de a publicação não aparecer para muitas pessoas e você não ter um número de curtidas bom. Apesar que agora eles tiraram o número de curtidas, né? Não aparece mais, mas a gente consegue ver. Então a gente consegue ver o número de curtidas, o alcance. Isso é um pouco chato quando acontece, mas já arquivei sim e já exclui sim também.

Entrevistada três: Então, o que já aconteceu comigo foi que me indicaram um produto e aí eu utilizei o produto e passei a dica para as seguidoras. Só que... quando a gente faz isso, a gente recebe muito mais comentários sobre o produto, né? E tinha muitas seguidoras falando que esse produto estava dando dor de cabeça, uma séria de sintoma nas pessoas e aí eu preferi apagar para não ser responsável, né? Até porque

RC: 105265

Disponível em: https://www.nucleodoconhecimento.com.br/comunicacao/olimpiano-digitais 
para mim deu certo, mas aí é muita responsabilidade dar uma dica de um produto assim que pode ter efeitos colaterais, então fui e apaguei.

Entrevistada quatro: Sim, já aconteceu sim. As pessoas enxergam de ângulos diferentes, né? Então, às vezes, eu tenho uma visão sobre determinado assunto e a pessoa tem outra visão. $\mathrm{E}$ as vezes, eu me permito que ela me faça refletir quando ela vem com argumentos estruturados, né, não simplesmente com xingamentos, mas com argumentos estruturados e tenta me explicar de maneira objetiva, eu me permito aprender. Eu acho que isso é extremamente importante para o nosso desenvolvimento como ser humano.

Entrevistada cinco: Olha, já aconteceu sim de eu postar alguma coisa, esperar um retorno x e não ter aquele retorno. Postar alguma coisa que eu achei que fosse bombar ou que a galera ia gostar muito, sabe? Alguma coisa assim desse gênero. Já teve situações de isso acontecer e eu ficar um pouco frustrada, triste porque não teve esse retorno. Não chegou a ter alguma coisa que eu postei que tivesse assim comentários negativos, mas já aconteceu de não ter o retorno, o engajamento que eu queria ou das pessoas não terem curtido assim igual eu esperava, né? Então, isso é até uma coisa que eu trabalho muito em mim, hoje em dia é mais trabalhado, eu não fico tão frustrada. Antigamente eu me sentia mais frustrada, mais triste quando isso acontecia. Hoje em dia eu já entendo que acontece. Depende também da ferramenta do Instagram. Mas antigamente eu me sentia muito mal por isso e já cheguei sim a apagar. Não muita coisa, mas uma coisa ou outro eu já cheguei a apagar sim. Outros eu simplesmente deixei lá e só fiquei com esse sentimento mesmo de frustração e de tristeza.

Pergunta 6 - Você sente que tem uma responsabilidade com os seus seguidores de estar postando constantemente? Você já se sentiu cobrada por eles?

RC: 105265

Disponível em: https://www.nucleodoconhecimento.com.br/comunicacao/olimpiano-digitais 
Entrevistada um: Então, eu sinto responsabilidade de postar frequentemente sim. Eu acho que é o meu compromisso com eles, né? Não que eu me sinta cobrada por eles, eu me sinto mais cobrada por mim do que pelos meus seguidores. Acho que é isso mesmo, eu me cobro muito.

Entrevistada dois: Olha, essa pressão de estar postando por conta dos seguidores, eu nunca senti. Até porque eu não sou muito cobrada nessa questão não. Durante a pandemia, eu senti que eles sentiram falta dos achados, mas entenderam que por conta da pandemia não dava para ficar fazendo achados. Ainda estamos em pandemia, né? Mas agora está um pouco mais flexibilizado. Mas mesmo assim não senti muita pressão dos seguidores quanto a isso não e eu fico até feliz. $\mathrm{O}$ que não pode acontecer é a gente deixar de postar por conta do Instagram. No Instagram você tem que estar sempre ali movimentando, porque senão, se você não postar um storie a sua bolina vai lá para trás, se você não fizer um post diariamente a sua interação vai cair. Então eu me sinto refém do Instagram, não dos seguidores em si porque os seguidores são maravilhosos quanto a isso. $\mathrm{E}$ o meu número de postagem é bem frequente mesmo então eu nunca deixei de postar, nunca fiquei uma semana sem postar, então nunca senti isso por conta dos seguidores porque eu nunca deixei de postar. Mas é claro que tem dias que a gente não quer postar e tudo mais, mas também não sou cobrada pelos seguidores quanto a isso. Mas eu sei que eu tenho responsabilidade por conta do Instagram mesmo, para não deixar o alcance cair. Me sinto refém do Instagram, não dos seguidores.

Entrevistada três: Sinto por eles e também pelo engajamento porque eu sei que se eu parar de postar o engajamento vai cair e muitas pessoas não vão receber o conteúdo. Então eu sempre tenho que me dedicar para estar postando ou nos stories ou no feed. Criando algo novo para gerar engajamento e atingir mais pessoas.

Entrevistada quatro: Sim, sim, eu tenho responsabilidade sim. Principalmente porque isso é um trabalho, né? Então eu não posso simplesmente sumir. EU tenho que dar

RC: 105265

Disponível em: https://www.nucleodoconhecimento.com.br/comunicacao/olimpiano-digitais 
uma justificativa sim. E já aconteceram vezes que eu não estou bem psicologicamente e tenho que parar e aí eu recebo mensagem, elas querem saber. E está tudo bem porque isso significa que eu construí u vinculo bacana com elas, né, a ponto delas sentiram falta quando eu não apareço. Mas eu me vejo na responsabilidade sim de dar uma satisfação, de falar quando eu não posso aparecer o que aconteceu. Então, além de ser um trabalho, eu tenho essa responsabilidade com o meu conteúdo, com o que eu ofereço para elas, então tem uma responsabilidade sim quanto a isso.

Entrevistada cinco: Eu nunca me senti cobrada assim... já me cobraram, mas eu nunca senti que estão me cobrando por uma obrigação. Eu e cobro muito de sempre estar postando. Por exemplo, eu odeio, odeio é uma palavra muito forte, mas eu não curto muito postar uma publicidade atrás da outra. Sempre tento conversar com a marca ou com o cliente da gente ver, de postar, né? Pelo menos intercalar, um conteúdo orgânico, uma publicidade... Então assim, eu me sinto um pouco incomodada quando eu posto dias publicidades seguidas porque eu sei que a galera não gosta de ver muita publicidade seguida, né? Não é muito legal. Por mais que seja sempre assuntos que tem a ver com o meu Instagram e tudo mais. Então, eu me cobro muito nessa questão e me cobro muito de ter essa responsabilidade de estar sempre postando, de estar constantemente trazendo conteúdo, de estar inovando. Eu sinto essa responsabilidade muito grande, mas que parte de mim mesmo. É muito difícil eles me cobrarem alguma coisa porque por eu ter essa própria cobrança comigo mesma, acaba que não sobra tempo para eles me cobrarem porque eu não sou muito de sumir e não postar, sabe?

Pergunta 7 - Quanto tempo em média você dedica as redes sociais?

Entrevistada um: Ah o tempo é quase 24 horas, de verdade. Assim, as vezes eu tiro um dia, né? Para poder gravar e tudo mais, só que aí no outro dia eu já vou para várias lojas, vou para vários lugares, vou fazer várias divulgações... Aí quando eu não estou

RC: 105265

Disponível em: https://www.nucleodoconhecimento.com.br/comunicacao/olimpiano-digitais 
gravando ou não estou em alguma loja, eu estou editando alguma coisa para alguma loja. Então é muito complicado o tempo. Muito, muito complicado.

Entrevistada dois: Isso depende. Agora na pandemia eu estou ficando mais tempo porque eu não estou trabalhando no momento né, porque eu sou professora. Então eu estou tendo mais tempo e achoo que estou gastando umas nove horas diárias aí, senão até mais.

Entrevistada três: Acho que ficou em média 5/6 horas por dia.

Entrevistada quatro: Mais de 10 horas por dia. Em torno de 12 horas por dia, mais ou menos. Olha só, agora são por volta de 1 hora da manhã e eu estou desde a hora que eu acordei me dedicando a rede social. Dei algumas pausas que são para poder ficar com a minha filha, mas são mais de 10 horas por dia me dedicando.

Entrevistada cinco: Eu dedico o meu dia todo, para ser bem sincera. Mesmo quando eu não estou num dia que eu estou trabalhando, que eu não estou ali para produzir o conteúdo, que eu não preciso produzir alguma coisa porque eu já produzi no dia anterior ou eu já tenho pra dois três dias. Mesmo quando eu não estou nessa produção de conteúdo, eu estou sempre ali editando, postando stories, trazendo conteúdo, mostrando a minha vida. Então assim, eu dedico praticamente $24 \mathrm{~h}$ porque eu estou sempre online, sabe? Tem dias que eu tiro para ficar off, mas mesmo esses dias que eu fico off, eu não fico off do Instagram, não fico off do Storie, não fico off de postar um conteúdo, eu só fico off de não produzir nada naquele dia entendeu? Então, eu dedico muito tempo a isso.

Pergunta 8 - Em algum momento você já pensou em desistir?

Entrevistada um: Várias vezes...

RC: 105265

Disponível em: https://www.nucleodoconhecimento.com.br/comunicacao/olimpiano-digitais 
Entrevistada dois: Pensar em desistir não. Nunca pensei em desistir não. Eu gosto muito, as vezes a gente cansa, não tá afim, mas desistir não.

Entrevistada três: Então, o algoritmo do Instagram sempre ta mudando, né, para dificultar e a gente patrocinar o conteúdo, então fica mais difícil de ter engajamento. Cada vez mais. Então já me bateu essas neuras de querer desistir, de estar sempre me reinventando.

Entrevistada quatro: Por incrível que pareça, mesmo com todas as dificuldades, desistir sempre foi a última opção quando se tratava da minha carreira porque é algo que eu sempre quis muito assim. Então, chegar ao patamar que eu cheguei, por mais que eu ainda tenha muitos degraus a galgar, para mim é uma realização muito grande, então, eu não penso em desistir. No máximo eu penso em dar alguma pausa, em parar alguns dias, mas desistir não.

Entrevistada cinco: Eu já pensei sim em desistir, vários momentos a gente pensa em desistir porque tem vezes que não está muito bom, que o retorno não está muito legal, tem vezes que a gente se sente muito estacionada, parada, que parece que a gente não sai do lugar, então passa sim pela cabeça desistir. Eu acho que todo mundo que trabalha com isso ou que quer trabalhar com isso já pensou em desistir. EU acho que é bem normal. Na real, eu acho que em todas as profissões a gente pensa em algum momento em largar tudo e desistir...

Pergunta 9 - Você já foi alvo de comentários maldosos? Já leu alguma coisa que te desagradou e te fez sentir mal consigo mesma?

Entrevistada um: Falaram mal do meu rosto porque eu estava com muitas... estou né, muitas marcas de acne e aí um monte de gente sem noção nos comentários. A Maybelline me respostou e aí muita gente falando que meu rosto era sujo e que nada a ver eu estar ali. Enfim, várias coisas desse tipo. Mas também já teve muita gente

RC: 105265

Disponível em: https://www.nucleodoconhecimento.com.br/comunicacao/olimpiano-digitais 
falando que eu era muito magrinha, essas coisas assim e mexeram muito, muito, muito comigo... demais.

Entrevistada dois: Já sim, já sim. Em relação até comentários assim preconceituosos. Já recebi comentários racistas, não muitos, mas já recebi. É bem chato quando isso acontece, né? E já recebi também comentários assim... posts de pessoas que não gostaram da publicação só que não sabem falar direito e aí falam com grosseria. As é como eu te falei, não discuto, eu excluo, bloqueio a pessoa e sigo a vida. Mas é uma situação muito chata, já passei por isso sim.

Entrevistada três: Sim, acontece. Eu passei por isso poucas vezes, mas acontece sim.

Entrevistada quatro: Recebo muito comentário maldoso, principalmente por aquilo que eu falei, quando a gente tenta ser autêntica e mostrar aquilo que a gente realmente pensa, né, sem tentar ser política, sem tentar agradar todo mundo, sem tentar ser neutra, as pessoas levam isso para o pessoal, né? Então elas ofendem mesmo, elas xingam e já aconteceu comigo sim.

Entrevistada cinco: Sim. Eu já fui alvo de críticas, de comentários negativos. Sempre tem uma pessoa, né? Um fake... um anônimo... No TikToker é uma coisa que acontece muito dependendo do que você posta. A galera lá é muito... no Instagram a galera ainda meio que se esconde, usa fake para mandar alguma coisa. No TikToker a galera já manda assim bem realzão mesmo. Então eu já fui. Às vezes você posta alguma coisa e a pessoa não tem a mesma opinião que você e ela vem e critica porque eu tenho a minha opinião. Ou as vezes eu conto um fato que aconteceu e a pessoa... sabe? Fala que eu estou exagerando ou me chama de alguma coisa. Então assim sempre tem um ou outro comentário negativo e é muito ruim. Isso me faz sentir muito mal. É uma coisa que o meu marido sempre fala... as vezes a gente abre o direct e tem lá, por exemplo, 50 directs de carinho, de pessoas falando coisas boas e tem um que te fala uma coisa ruim e você foca naquele que te fala uma coisa ruim. $O$ ruim de

RC: 105265

Disponível em: https://www.nucleodoconhecimento.com.br/comunicacao/olimpiano-digitais 
trabalhar com a internet é isso. É que além de a gente ficar focando no melhor, tem um ruim, um criticando, um falando merda né, criticando, e a gente foca nesse que está falando merda, que está criticando. Isso é muito ruim da internet. Porque a galera atrás de uma tela tem menos... não é noção, mas elas têm menos medo de falar alguma coisa, né? Então elas criticam e falam mesmo e se sentem no direito de falar porque você é uma pessoa pública.

Pergunta 10 - Você sente que ainda tem muito o que crescer ou está satisfeita com a sua posição atual?

Entrevistada um: Eu estou satisfeita, mas eu acho e tenho certeza de que eu ainda tenho muito para crescer. Mas assim, estou satisfeita com o meu momento, no caso. Só que a todo momento eu fico pensando em algo para poder explodir e crescer o mais rápido possível.

Entrevistada dois: Com certeza eu espero crescer mais e... a gente sempre quer, né? Alcançar mais, mas eu sou muito grata por tudo o que eu já alcancei até aqui e eu deixo as coisas acontecerem devagar... Eu tenho acho que uns 4 anos de Instagram, tem gente as vezes que ganha muitos seguidores muito rápido, eu não acho que eu ganhei tanto seguidor rápido assim, mas eu sou muito grata nisso. Mas é claro que eu almejo crescer ainda mais sim.

Entrevistada três: Eu sou grata, estou satisfeita sim, mas espero crescer ainda. A gente sempre quer, né?

Entrevistada quatro: Não, não estou satisfeita não. Eu quero ir muito mais longe e estou trabalhando para isso.

Entrevistada cinco: Eu sou grata pela posição que eu me encontro hoje, porém eu quero crescer mais, eu quero evoluir mais, eu quero conquistar mais coisas. Eu tenho

RC: 105265

Disponível em: https://www.nucleodoconhecimento.com.br/comunicacao/olimpiano-digitais 
metas que eu quero alcançar e ainda não alcancei. Então assim, sou grata, porém ainda não satisfeita.

Pergunta 11 - Você acha que os comentários têm poder em seus sentimentos?

Entrevistada um: Demais, demais, demais, eu ligo muito para a opinião das pessoas. Eu tenho que parar com isso, mas estou aprendendo a lidar aos poucos agora. Porém afeta muito nos meus sentimentos sim. O bom é que agora deu uma acalmada nos haters, vamos falar assim, está tudo mais tranquilo. As pessoas sempre me... os meus seguidores sempre me apoiam muito e sempre estão me botando para cima e tudo mais. Então isso já está bem melhor... esses sentimentos assim, sabe? Já está bem melhor.

Entrevistada dois: Olha, já passei por situações de preconceito, de racismo. Como o meu Instagram é de achados, eu não coloco muita coisa da minha vida, mas o pouco que eu coloco já sofri assim... comentários relacionados ao meu cabelo por eu fazer mexas loiras e ser negra. Como se não pudesse, como se tivesse "Ah, você é preta e tem que ter cabelo preto". Eu já ouvi coisas assim. Mas eu tento não ligar mesmo. Apago os comentários e sigo a vida.

Entrevistada três: Afeta, claro, mas tento não me importar muito e sempre focar no positivo.

Entrevistada quatro: Eu acho que poder não, mas eu acho que eles influenciam diretamente na nossa autoestima.

Entrevistada cinco: Sim, os comentários têm muito poder nos meus sentimentos, muito poder na minha vida, no meu dia a dia, é aquilo né? Quando a gente começa a ler comentários tanto negativos, como positivos, né, eles afetam muito a nossa vida, o nosso dia a dia, os nossos sentimentos, a nossa maneira de pensar. Às vezes a gente posta uma coisa e tal achando que tá né... e aí vem uma pessoa falando uma

RC: 105265

Disponível em: https://www.nucleodoconhecimento.com.br/comunicacao/olimpiano-digitais 
coisa e você começa a pensar, analisar se aquela pessoa não está certa e você errada. Então os comentários sim, eles influenciam demais o nosso dia a dia.

\section{APÊNDICE - REFERÊNCIA NOTA DE RODAPÉ}

3. Doravante, o termo redes social refere-se exclusivamente as redes sociais da internet.

4. Não existe uma definição oficial para o conceito de saúde mental, de acordo com a Organização Mundial de Saúde (OMS). O termo está relacionado à forma como uma pessoa reage às exigências, desafios e mudanças da vida e ao modo como harmoniza suas ideias e emoções. Podemos dizer que a saúde mental contempla, entre tantos fatores, a nossa capacidade de sensação de bem-estar e harmonia, a nossa habilidade em manejar de forma positiva as adversidades e conflitos, o reconhecimento e respeito dos nossos limites e deficiências, nossa satisfação em viver, compartilhar e se relacionar com os outros -algo muito maior e anterior ao início dos transtornos mentais.

5. As Teorias da Comunicação são uma série de estudos sobre a Comunicação Social, podendo englobar filosofia, sociologia e psicologia, a depender do tipo de abordagem e da área a ser estudada. Essas teorias estudam o desenvolvimento e a aplicação da Comunicação Social em todos os seus aspectos políticos, sociais, econômicos e tecnológicos. Tais estudos começaram a se desenvolver a partir do início do uso da Comunicação de Massa pelas políticas totalitárias da Europa no período entreguerras.

6. Do Dicionário Domingos Paschoal CEGALLA:

o. $\lim \cdot$ po

substantivo masculino

1. Monte da Grécia, mitológica morada dos RC: 105265

Disponível em: https://www.nucleodoconhecimento.com.br/comunicacao/olimpiano-digitais 
2. Lugar das delícias, céu, paraíso: Há um olimpo reservado para os

7. A Revolução Industrial foi o período de grande desenvolvimento tecnológico que teve início na Inglaterra a partir da segunda metade do século XVIII e que se espalhou pelo mundo causando grandes transformações. A Revolução Industrial garantiu o surgimento da indústria e consolidou o processo de formação do capitalismo.

8. A Revolução Francesa foi um movimento político-social de revolta da burguesia ocorrido na França em 1789 quando a crise econômica afetava o país.

9. A sociedade disciplinar é uma elaboração de Michel Foucault para explicar a configuração da sociedade europeia no período de ascensão do capitalismo e gradativa queda do poder monárquico. Nas sociedades disciplinares, as instituições sociais assumem papéis de vigilância, normatização e exame constante dos sujeitos, de tal maneira que o poder, exercido minuciosamente, marca os corpos e lhes impõe condutas.

10. @eukerensalles, @alokdosachados, @entre.amigasz, @brunadantas.blog e @giovannacomdoisn e

11. Forma como são conhecidos os perfis que reúnem peças garimpadas nas lojas físicas. Assim, em vez de horas gastar indo de loja em loja, basta buscar as melhores ofertas e opções nas páginas online.

Enviado: Dezembro, 2021.

Aprovado: Janeiro, 2022.

RC: 105265

Disponível em: https://www.nucleodoconhecimento.com.br/comunicacao/olimpiano-digitais 